\title{
Sharing Fake News about Health in the Cross-Platform Messaging App Whatsapp during the COVID-19 Pandemic: A Pilot Study
}

\author{
${ }^{1}$ David Araújo Pinheiro, ${ }^{1}$ Mariana Gomes Leitão de Araújo ${ }^{*},{ }^{1}$ Keilla Barbosa de Souza, ${ }^{1}$ Beatriz de \\ Sousa Campos, ${ }^{1}$ Evanete Maria de Oliveira, ${ }^{1}$ Rosa Stephanny Melquides Lima, ${ }^{1}$ Gabriella Alves \\ Ferreira, ${ }^{1}$ Aila Caterine Almeida de Freitas, ${ }^{1}$ Caroline Barbosa Toledo, ${ }^{1}$ Gabriela Brito de Souza, \\ ${ }^{1}$ Thais Ranielle Souza de Oliveira, ${ }^{1}$ Daniel Fernandes Barbosa
}

${ }^{1}$ Euro American University Center — UniEuro, Brasília, Brazil

\begin{abstract}
In the current scenario of the COVID-19 pandemic, a lot of false information has spread through social networks. This study aimed to characterize the types of fake news in health and the factors that influence its sharing. This is a descriptive cross-sectional observational study conducted by health scholars who analyzed the messages received in the WhatsApp network and the sociodemographic characteristics of sharers in the year 2020. Results: The level of education influences the spread of false news, and family members have a higher frequency of sharing these news. As for the type of content of fake news, the fabricated content and false context stood out as the most shared ones. The characteristic of the group of researchers may have influenced the receivement of a smaller amount of fake news, since they are able to recognize and refute.
\end{abstract}

Keywords: Fake news, WhatsApp, SARS-CoV-2, Pandemic.

\section{Introduction}

Technological advances were crucial for the development of communication, so the world became more connected due to greater digital interactivity. People began to have access to information immediately, thus acquiring the ability to disseminate it to any part of the world in a matter of seconds, whether true or not.

In this context, fake news are characterized by their contemporaneity, if there is a widely disseminated subject, there will certainly be fake news about this content. The current pandemic caused by the new Coronavirus, a public health emergency of international importance, has become the most discussed topic in different spheres of society, and many rumors about the disease have been detected by the Ministry of Health, requiring health authorities to adopt communicating and informing the population and press as fundamental strategies for coping with the pandemic. (Oliveira et al., 2020).

According to Wardle and Derakhshan (2017), with regard to content, the fake news are classified into seven types: skits and/or parodies, whose potential is misleading, without intent to cause damage; misleading content: makes use of misleading information in order to group a problem or individual; impostor content: is used on-site names, people, genuine information sources, but with false information with the intent to deceive; manufactured content: the content is $100 \%$ false, intended to deceive and harm the reader; false connection: when the image or text does not match the content presented; false context: when the content is true but is shared with false context; manipulated content: when the true information is handled with the purpose of deceiving the people.

Thanks to the emergence of social networks, messaging applications and the speed of information sharing, fake news has gained great potential for dissemination through the current tools used for communication in the world, with WhatsApp as the highlight, created in 2009 as an application (App ) of multimedia sharing, which today is the most popular communication tool in countries like Brazil, India, and Mexico (Melo et al., 2019).

WhatsApp is easy to access, allowing users to exchange information that suits them individually or in 
groups (Melo et al., 2019; Resende et al., 2019). Contains end-to-end encryption, so all text, voice, and media messages are protected; these documents are viewed only by those involved in communication (Resende et al., 2019). Worldwide, approximately 1.5 billion people use WhatsApp in 180 different countries (Melo et al., 2019). According to Teixeira and Santos (2020), around 120 million users in Brazil use this tool.

This application is considered by experts as the largest multiplier of fake news in a private digital environment with high interactivity index (Teixeira et al., 2020). Analyzing it as the main means of disseminating false news related to Coronavirus, there has been a higher frequency of falsified content compared to other social networks, such as Twitter, which reaches $14.1 \%$ while WhatsApp reaches $24.7 \%$ of shared fake news, mostly through textual messages, because they are common and easy to manipulate (Salaverría et al., 2020). Sharing fake news can be extremely harmful to health. An example of this phenomenon has been the growth of the anti-vaccination movement worldwide, causing a strong impact on the vaccination coverage of the population and causing the resurgence of infectious diseases previously controlled by immunization (Saraiva; Farias, 2019).

Faced with a still unknown scenario in the COVID-19 pandemic, there was an increase in the spread of false news with topics that addressed both the prevention of the disease and its possible treatments through miraculous therapies without a scientific basis, which can generate serious damage (Matos, 2020). The consequences affect the population in general by mitigating the risks of certain pathologies, as well as trivializing their care, making it impossible to cope effectively with these diseases. (Monnari; Son, 2019).

Therefore, health professionals emerge as pillars in combating false information, according to Lavorgna et al., (2018), the critical evaluation of health professionals tends to curb the impetus of the dissemination of fake news. However, despite the technical knowledge presented by these professionals, it is necessary to develop effective methods aimed at combating this false information, since there is a gap in relation to how to deal with these news (Ribeiro 2018). According to Castro et al., (2020), when an individual is inserted in the academic environment, there is a requirement in regard to reading capabilities and development of scientific and critical thinking, so the academic environment tends to suppress the spread of false news.

Based on the above, the objective of this study was to characterize the types of fake news in the health area and to denote the factors that influence sharing among a group of academics in this area during the COVID19 pandemic, via the multi-platform application, WhatsApp. The following hypotheses were established: that sociodemographic aspects influence the sharing of information in the app; there is a predominance in the type of content of fake news shared during the COVID-19 pandemic, and groups consisting of individuals in the health area tend to receive less false news.

\section{Methodology}

A descriptive cross-sectional observational study, a Pilot Study in character, carried out from April 28 to May 28, 2020, to outline the profile of individuals involved in the propagation of fake news, as well as to classify the content of misinformation contained in the messages received. A convenience sampling was carried out, consisting of 22 components of the research project on health promotion strategies at a University Center in the Federal District-Brazil. The components belonged to the Nursing, Pharmacy, Physiotherapy, and Dentistry courses.

Regarding data collection, messages were received on WhatsApp social media by people belonging to the social circle of the researchers involved, and their identification as fake news was carried out manually. In all, the project components had a total of 4,411 contacts, with 250 groups being followed within the application and classified into 20 family groups, 114 friends/diverse groups, and 116 professional groups. The identification and confirmation of the information received as fake news was carried out through the analysis of a specialist and the use of fact-checking sites "aos fatos" and "a Lupa" belonging to the International Fact-Checking Network (IFCN). With the scope of protecting participants' anonymity, no records were stored that could identify them.

Regarding the content, the fake news was classified, according to Wardle and Derakhshan (2017), by type: Content Manipulation, Manufactured Content, False Connection, False Context, Deceptive Content, Satire or Parody and Impostor Content. On a continuous basis, they were quantified using descriptive statistics, to 
make known the types of fake news most prevalent in the participants' social network. The subsets were organized and analyzed, according to the keywords by subject and keywords that pointed to the false news, for better dissociation of the content and, subsequently, grouped according to the order of prevalence that indicated which terms were more frequent in the collection period.

The notes of the messages received as fake news were recorded in a provisional table in Excel, with the organization of qualitative variables of the content of the message and the sender, in the collected data were inserted: gender, age, profession, education level, type of relationship (friend, family, acquaintance and stranger), whether received privately or in WhatsApp groups, the type of message (video, text, audio, print, and photo), the theme of the news and its main subject, considering that most were about COVID-19.

In the organization of the data, the non-receivement of fake news should be recorded, in order not to change the search result. The fake news collected were inserted into a WhatsApp group, created to transfer the information to the definitive spreadsheet, resulting in a number with the total information presented during this period.

For statistical analyses, the Minitab program (2020) was used to verify the association between sociodemographic aspects and the sharing of fake news; on the other hand, for the comparison between the types of content of the fake news, the chi-squared test was used, being considered significant, where $\mathrm{P}<0.05$.

\section{Results/Discussion}

The present study recorded 31 messages that were proven to be false, considering that the participants are students in the health area, it is understood that there may be a relationship with the small amount of news received. According to Lavorgna et al., (2018), health care individuals tend to curb and contain the spread of fake news when it is identified.

The distribution of fake news by sociodemographic characteristics was as follows: most of the sharers, $52 \%$, were male, while $48 \%$ were female (TABLE 1), however, according to Shu et al., (2018), female individuals are more likely to trust false news than male individuals. Although there is a difference in the percentage of gender, what can be inferred is that the results of the present study resemble those of the current literature.

Table 1. Sociodemographic variables related to the sharing of fake news in the WhatsApp application.

\begin{tabular}{|l|l|l|}
\hline Sex & $\mathrm{N}$ & $\%$ \\
\hline Male & 16 & 52.00 \\
\hline Feminine & 15 & 48.00 \\
\hline Age & $\mathrm{N}$ & $\%$ \\
\hline $60 \mathrm{ou}+$ & 8 & 26.00 \\
\hline $40-49$ years & 7 & 23.00 \\
\hline $30-39$ years & 6 & 19.00 \\
\hline $50-59$ & 5 & 16.00 \\
\hline Not identified & 3 & 10.00 \\
\hline $20-29$ years & 2 & 6.00 \\
\hline Up until 19 years & 0 & 0,00 \\
\hline Education & $\mathrm{N}$ & $\%$ \\
\hline Incomplete Elementary School & 1 & 3.00 \\
\hline Complete Higher Education & 9 & 29.00 \\
\hline Complete High School & 8 & 26.00 \\
\hline Unknown this information & 8 & 26.00 \\
\hline Incomplete Higher Education & 3 & 10.00 \\
\hline Complete Primary Education & 2 & 6.00 \\
\hline Incomplete High School & 0 & 0,00 \\
\hline Relationship Category & $\mathrm{N}$ & $\%$ \\
\hline Family & 19 & 61.00 \\
\hline Friend & 5 & 16.00 \\
\hline
\end{tabular}




\begin{tabular}{|l|l|l|}
\hline Known & 4 & 13.00 \\
\hline Unknown & 3 & 10.00 \\
\hline
\end{tabular}

Regarding age, the predominant group, $26 \%$, was people aged 60 years or older, $23 \%$ for individuals aged 40-49 years and 19\% people aged 30-39 years (TABLE 1), a similar profile reported by Manso et al., (2019), in which people aged 60 years or older tend to share more fake news, because they have less ability to discern what are facts and what are false news, so they share up to seven times more than people from other age groups.

Considering education, it was observed that $29 \%$ were people with complete higher education, $26 \%$ were people with completed high school, and it was not possible to identify this information in $26 \%$ of the cases (TABLE 1). Analyzing the study by Jones-Jang et al., (2019), it appears that users with higher education are better able to recognize and refute false news. Considering the profile of the research components, it was observed that because the researchers are inserted in the academic environment, the relationship with this social circle may have interfered with the results obtained. It is known that the environment in which the individual is inserted influences his niche of interpersonal relationships.

Still, on the level of education, the study by Morais and Sobral (2020), showed that most students are aware of what fake news is, of the negative impact of the phenomenon and that most students have a high level of distrust in the information shared through social networks, thus pointing to education as the best way to reduce the impact of fake news.

Regarding the relationship category of fake news sharers, in $61 \%$ of cases, fake news was shared by family members, $16 \%$ by friends, $13 \%$ by acquaintances, and $10 \%$ by strangers (TABLE 1). Considering the study conducted by Resende et al. (2019), it was observed that family groups are responsible for $51 \%$ of the sharing of untrue information in Whatsapp media during the presidential campaigns in Brazil in 2018. These findings can be related to the fact that the individual has greater confidence when sending the content of a deceptive content to a family member, due to their degree of proximity, according to Sousa Júnior et al., (2020) this misinformation is called involuntary.

Relating to the types of fake news media, it was found that in $35 \%$ of the cases the fake news were in text format, $32 \%$ in video, $19 \%$ in audio, and $13 \%$ were shared through a news photo/print (TABLE 2). Tandoc et al., (2017), state that there is a greater occurrence in the sharing of false information in news/print, given the fact that its falsification has a more common occurrence associated with the use of manipulation software. In reference to the results obtained by Salaverría et al., (2020), false news tends to be more shared in the form of text because it is easy to produce. Generally, at the time of the dissemination of fake news, the text will be associated with the image or a video. According to Matos (2020), fake news in a general context does not tend to be much shared through audio due to higher demand from the receiver. According to Moroni (2018), the high rate of sharing fake news through videos is associated with its ability to impact and generate emotion in the recipient.

About fake news by shared subjects, $77 \%$ were content related to health, $19 \%$ were involved in politics, and $3 \%$ related to beliefs (TABLE 2). According to the study by Salaverría et al., (2020), in which the prevalence of the most recurrent subjects in the sharing of fake news was analyzed, $34.9 \%$ of the false news corresponded to the category of Science and Health, 26.7\% to the Politics and Government and $38.4 \%$ to other matters. It becomes evident that most of the fake news related to Health will be politicized (Salaverría et al., 2020). 
Table 2. Themes, content types and media of cataloged fake news.

\begin{tabular}{|l|l|}
\hline Fakes news themes & $\mathbf{N}(\boldsymbol{\%})$ \\
\hline Subject of the health & $24(77,42)$ \\
\hline Policy & $6(19,35)$ \\
\hline Beliefs & $1(3,23)$ \\
\hline Content Type & $\mathbf{N}(\%)$ \\
\hline Manufactured Content & $11(35,00)$ \\
\hline Deceptive Content & $9(29,00)$ \\
\hline Handled Content & $6(19,00)$ \\
\hline Impostor content & $3(10,00)$ \\
\hline False Context & $2(6,00)$ \\
\hline Shared media type & $\mathbf{N}(\%)$ \\
\hline Text & $11(35,00)$ \\
\hline Vídeo & $10(32,00)$ \\
\hline Áudio & $6(19,00)$ \\
\hline Photo of the news (print) & $4(13,00)$ \\
\hline
\end{tabular}

Concerning the classification of the type of content in fake news, 35\% were manufactured content; $29 \%$ misleading content; $19 \%$ manipulated content; $10 \%$ imposter content and $6 \%$ content with false context (TABLE 2). Salaverría et al., (2020) found results opposite to this study and reported that fake news of the impostor content type were more prevalent.

There was no association between sociodemographic aspects and the sharing of fake news by the chi-square test. When using the classification of content types and sociodemographic variables, gender $(\mathrm{p}=0.457)$, age $(\mathrm{p}=0.508)$, schooling $(\mathrm{p}=0.616)$ and relationship type $(\mathrm{p}=0.331)$ there were no significant differences (TABLE 3). Similar results were found in the study by Yamaguchi et al., (2020) in which they highlighted that, in regards to interpretation, evaluation and use of health information in digital media, the variables sex and age were not associated with the sharing of fake news, different from the education variable, which was significant.

When comparing the classification of content types, it was found that the manipulated content, deceptive content, and impostor content did not show differences in their frequencies. However, the fabricated content and false context stood out as the most shared $(p=0.033)$. Similarly, a study by Ferreira (2018) that analyzed the content on the web, reveals that the main contents, the "false context" and the "fabricated content", are the most motivating for propagation (TABLE 3 ). 
Table 3. Results of the Chi-square test for the association between qualitative variables and classification of fakes news; content types and classification and association between content type and media.

\begin{tabular}{|l|l|l|}
\hline Answer & Factor & P value \\
\hline Sex & Classification & 0,457 \\
\hline Scholarity & Classification & 0,508 \\
\hline Relationship Type & Classification & 0,616 \\
\hline Handled Content & Classification & 0,331 \\
\hline Manufactured Content & Classification & $>0,05$ \\
\hline False Context & Classification & $0,033^{*}$ \\
\hline Deceptive Content & Classification & $0,033^{*}$ \\
\hline Text & Classification & $>0,05$ \\
\hline Video & Media & $>0,05$ \\
\hline Áudio & Media & $>0,05$ \\
\hline Photo of the news (print) & Media & $>0,05$ \\
\hline
\end{tabular}

* - Test Qui $^{2}(\mathbf{p}<0,05)$

There was no association between the type of shared media and gender, age, schooling, and relationship types ( $p>0.05$ ); as well as the types of media: text, video, audio, and photo of the news (print) ( $p>0.05)$. It should be noted that although there is no statistical association in this study, sociodemographic factors may influence the sharing of fake news, it is understood that these factors are characterized as social determinants of health, so they condition the spread of fake news(Yamaguchi et al., 2020; Guntzviller et al., 2016) (TABLE 3).

\section{Conclusions}

The dissemination of fake news has several variables, being dependent on a medium in which to propagate itself. The most common means of sharing nowadays is the WhatsApp message sharing network, being the favorite among fake news spreaders because of its accessibility and easy use.

After the analysis of the results of the present study, it is inferred the need to deepen investigations in this subject, to demonstrate that sociodemographic factors can influence the sharing of news without factual, true, content. In this context, health professionals can collaborate as part of a process aimed at combating this problem of spreading fake news in an international emergency moment in the face of the COVID-19 pandemic.

It is noteworthy that, with respect to the fight against fake news, there is a strong need to improve the continuing education of these professionals, to curb the spread in the environment in which it is inserted. Therefore, for future studies, it is suggested to characterize whether the fake news was shared in groups or individually on the WhatsApp message sharing network to deepen the profile of the dissemination of such news in this application, which can contribute to the improvement and decrease the dissemination of false news, especially in health in times of pandemic and other topics of social importance.

\section{Acknowledgements}

The authors thank all the members of the extension project Strategies for Health Promotion and Disease 
Prevention who contributed hard to the collection of data to carry out this research.

\section{Authors' contributions}

Oliveira, T.R.S worked on the design of the study. Oliveira, E.M, Pinheiro, Araújo, Souza, Campos and Freitas worked in data collection, organization of information and elaboration of results and discussion. Lima, Ferreira, Toledo, and Souza participated in the data collection and elaboration of the text. Oliveira, T.R.S and Barbosa deepened the discussion and made final revisions in the body of the text.

\section{References}

[1.] Castro; et al. Perspectiva de graduandos da UFMG a respeito das fake news. In: Congresso Nacional Universidade, EAD e software Livre. 2020, Minas Gerais v.1, n.11 p. 1-6.

[2.] Ferreira, R. R. Rede de mentiras: a propagação de fake news na pré-campanha presidencial brasileira, 2018. Faculdade de letras da Universidade de Coimbra- FLUC. Portugal, 2018.

[3.] Filho, O. F. O que é falso sobre fake news. Revista Usp. São Paulo, n. 116, pág. 39-44, 29 maio 2018.

[4.] Guntzviller, L; King, A; Jensen, J; Davis. Self-Efficacy, Health Literacy, and Nutrition and Exercise Behaviors in a Low-Income, Hispanic Population. Journal of Immigrant and Minority Health, v. 19, n. 2, p. 489-49, 2016.

[5.] Jones-Jang, S. Mo et al. Does Media Literacy Help Identification of Fake News? Information Literacy Helps, but Other Literacies Don’t. American Behavioral Scientist, Columbia, pág. 1-18, 01 nov. 2019.

[6.] Lavorgna, L. et al. Fake news, influencers and health-related professional participation on the Web: a pilot study on a social-network of people with multiple sclerosis. Multiple Sclerosis And Related Disorders, v. 25, pág.175-178, 14 out. 2018.

[7.] Maros, A. et al. Analyzing the Use of Audio Messages in WhatsApp Groups. In: Anais the Web conference, 2020, Taipei, Taiwan.

[8.] Manso, M. E. G; Vallada I. B. P; Hluchan K.; Oshiro L. V. S. Fake News e Saúde da Pessoa Idosa. Rev. Longeviver, São Paulo, 2019. n. 2, p. 19-25.

[9.] Matos, R. C., Fake News frente a pandemia de COVID-19. Revista Visa em Debate: Sociedade, Ciência e Tecnologia, Belo Horizonte, p. 1-8, 2020.

[10.] Melo P. F. et al. Can WhatsApp Counter Misinformation by Limiting Message Forwarding? In: International Conference on Complex Networks and Their Applications. Springer, Cham, 2019. p. 372-384.

[11.] Melo, P.; Messias, J.; Resende, G.; Garimella, K.; Almeida, J.; Benevenuto, F. Monitor de WhatsApp: um sistema de verificação de fatos para WhatsApp. Proceedings of the International AAAI Conference on Web and Social Media, v. 13, n. 01, p. 676-677, 6 de julho de 2019.

[12.] Morais, N. S; Sobral, F. Desafios da desinformação e das fake news: estudo de caso com estudantes do ensino superior. Millenium, 2 (ed. espec $\mathrm{n}^{\circ}$ 5) p. 85-93, v. 5, 11 nov. 2020.

[13.] Monari, J. Possíveis impactos de Fake News na percepção-ação coletiva. Rev. Fill. Tem, BelémPA, 2018. v.3, n.1, p.130-160.

[14.] Monari, A. C. P.; Bertolli F. C., Saúde Sem Fake News: Estudo e Caracterização Das Informações Falsas Divulgadas No Canal De Informação E Checagem De Fake News Do Ministério Da Saúde. Revista Mídia e Cotidiano, São Paulo, 2019 v. 13, n. 1, p. 160-186.

[15.] Minitab. Versão 19: Minitab Statistical Software, 2020.

[16.] Neto, M. et al. Fake news no cenário da pandemia de COVID-19. Cogitare Enfermagem, Rio de Janeiro, p. 1-7, 2020.

[17.] Oliveira, W. K. et al. Como o Brasil pode deter a COVID-19. Epidemiol. Serv. Saúde, Brasília, v. 29, n. 2, p. 1-8, abr. 2020.

[18.] Resende, G. et al. (Mis)Information Dissemination in WhatsApp: gathering, analyzing and countermeasures. The World Wide Web Conference, California, p. 818-828, maio 2019.

[19.] Ribeiro, B. C. M. S.; Franco, I. M.; Soares, C. C. Competência em informação: As fakes news no contexto da vacinação. Múltiplos Olhares em Ciência da Informação, Minas Gerais, p. 1-15, nov. 2018.

[20.] Salaverría, R. et al. Desinformación en tiempos de pandemia: tipología de los bulos sobre la covid- 
19. El Profesional de La Información, España, v. 29, n. 3, p. 1-15, may 2020.

[21.] Saraiva L., Farias J. A Ciência e a Mídia: A propagação de Fake News e sua relação com o movimento anti-vacina no Brasil. IN: 42 ${ }^{\circ}$ Congresso Brasileiro de Ciências da Comunicação, 2019, Belém - PA, anais, p. 1-15.

[22.] Sousa Junior, J.H.; et al. Da Desinformação ao Caos: uma análise das Fake News frente à pandemia do Coronavírus (COVID-19) no Brasil. Cadernos de Prospecção - Salvador, v. 13, n. 2, Edição Especial, p. 331-346, abr. 2020.

[23.] Shu, K. et al. Understanding User Profiles on Social Media for Fake News Detection. Ieee Conference On Multimedia Information Processing And Retrieval (mipr), Miami, p. 1-6, 2018.

[24.] Tandoc Jr. E C.; Lim Z. W.; Ling R. Defining "FakeNews". A typology of scholarly definitions. Digital Journalism, v. 6, n. 2, p. 137-153, 30 ago. 2017.

[25.] Teixeira, A.; Santos, R.C. Fake news colocam a vida em risco: a polêmica da campanha de vacinação contra a febre amarela no Brasil. RECIIS- Revista Eletrônica de Comunicação, Informação e Inovação em Saúde, Rio de Janeiro, v. 14, n. 1, p. 72-89, jan./mar. 2020.

[26.] Wardle, Claire; Derakhshan, Hossein. Information Disorder: toward an interdisciplinary framework for research and policy making. Strasbourg: Council Of Europe, 2017. 109 p.

[27.] Yamaguchi, Mirian Ueda et al. O papel das mídias digitais e da literacia digital na educação nãoformal em saúde. Revista Eletrônica de Educação, v. 14, p. 3761017, 15 jan. 2020. 